Revista de Ciencias Sociales - Número 68 (2016) - Páginas 105-136

Evaluación y racionalización de la reforma de los delitos contra la libertad sexual

\title{
EVALUACIÓN Y RACIONALIZACIÓN DE LA REFORMA DE LOS DELITOS CONTRA LA LIBERTAD SEXUAL
}

\author{
EVALUATION AND STREAMLINING TO \\ THE REFORM OF THE CRIMES \\ AGAINST SEXUAL FREEDOM
}

JOSÉ LUIS GUZMÁN DALBORA*

Centro de Investigaciones de Filosofía del Derecho y Derecho Penal

Universidad de Valparaíso (Chile)

joseluis.guzman@uv.cl

\section{Resumen}

El artículo repasa y enjuicia la reforma a los delitos contra la libertad sexual en Chile a partir de la modificación inicial, en 1999, poniendo de manifiesto cómo las modificaciones sucesivas han perdido de vista la libertad como objeto de tutela y colocado en su lugar exigencias moralizantes, de integrismo en la esfera de la sexualidad. Examina y critica su régimen en los últimos proyectos de reforma total al Código vigente, y formula algunas

\footnotetext{
* Profesor titular de Derecho penal y de Introducción a la Filosofía moral y jurídica en la Universidad de Valparaíso (Chile). Este artículo se origina en el Informe que el autor presentó al Seminario organizado por el Centro de Estudios de Derecho penal y procesal penal Latinoamericano de la Universidad de Gotinga (Alemania) en marzo y abril de 2015, acerca de la reciente reforma penal en Chile. Artículo recibido el 2 de marzo de 2016 y aceptado el 27 de mayo de 2016.
}

Revista de Ciencias Sociales - Número 68 (2016) - Universidad de Valparáíso - ISSN 0716-7725-Valparaíso, Chile 
propuestas político-criminales para una racionalización de esta maltratada materia.

\section{Palabras clave}

Libertad sexual, reforma penal, moralidad, homofobia, autoritarismo.

\section{Abstract}

The paper reviews the reform of the crimes against sexual freedom in Chile from the first modification in 1999. It shows that the following reforms have lost the way of sexual freedom, replacing it with moralistic claims, that is, the fundamentalism in the sexual sphere. Analyzes and criticizes his regime in recent projects of total reform of the Criminal code (1874), and makes some political-criminal proposals for a rationalization of this battered matter.

Keywords

Sexual freedom, penal reform, morality, homophobia, authoritarianism.

\section{La modificación de 1999 a estos delitos}

Los delitos contra la libertad sexual han sido objeto de numerosísimas modificaciones en los últimos años, afán de innovación en que son superados sólo por los delitos contra la propiedad ${ }^{1}$.

Por cierto, el concepto «libertad sexual» lo asumimos aquí en un sentido político-criminal, esto es, como base para la reconfiguración futura de estas infracciones, no ya porque el Derecho vigente permita reconducirlas sin más a dicho objeto de tutela. Asimismo, empleamos el substantivo innovación en el significado estricto del verbo subyacente, mudar algo introduciéndole novedades, absteniéndonos de sugerir que las aparecidas en la balumba de reformas sean dignas de aprecio ni que respondan a una política criminal precisa en la materia.

1. Cfr. OLIVER CALDERÓN, Guillermo: Delitos contra la propiedad, Legalpublishing-Thomson Reuters, Santiago de Chile, 2013, págs. 22-29, y nuestra recensión de esta obra en la Revista de Ciencias Penales, del Instituto de Ciencias Penales, Santiago de Chile, Sexta Época, volumen XLI, número 3, 2014, págs. 277-285.

Facultad de Derecho y Ciencias Sociales - Universidad de Valparaíso - Chile 
En verdad, las primicias de que haremos somero repaso han surgido de la presión de circunstancias imaginarias o agigantadas en su entidad, azarosa e improvisadamente, faltas de un hilo dogmático conductor, carentes de respaldo criminológico y ayunas de orientación política. En esta marcha a trompicones, la legislación de los últimos tres lustros ha conseguido expandir las figuras delictivas, agravar las penalidades correspondientes y desproporcionarlas tanto respecto del bien jurídico que se dice ofenderían como en comparación con la tutela que el Código dispensa a bienes que poseen mayor significación individual. Algo semejante viene sucediendo en los delitos contra la propiedad, y en ambos casos el fenómeno traiciona una actitud voluntarista de inequívoco autoritarismo².

Tanto es así, que los juicios reprobatorios que personalmente vertimos al evaluar la primera gran reforma de estos delitos, obra de la Ley número 19.617, de 12 de julio de 1999, parécenos hoy excesivos a la luz de lo que sobrevendría en los años siguientes ${ }^{3}$. Pese a los signos de alarma, que dejaban entrever el rumbo legislativo-penal del país ${ }^{4}$, no

2. Existe otro factor modelador de este panorama, que se esconde detrás de la reforma de los delitos de hurto y robo, aunque no deja de influir también en el exacerbado castigo de la violación: el prurito de proteger especialmente los intereses de un determinado sector social, minoritario pero muy poderoso, o, a lo menos, tranquilizarlo simbólicamente en sus temores. Cfr. GUZMÁN DALBORA, José Luis: "Bosquejo y apreciación de la reciente reforma penal en Chile". En: Díez Ripollés, José Luis, y García Pérez, Octavio: La política legislativa penal iberoamericana en el cambio de siglo, Edisofer y B. de F., Madrid y Buenos Aires-Montevideo, 2008, págs. 167-199.

3. Véase nuestro artículo "Apreciación y reprobación de la reforma de los delitos contra la honestidad en Chile", publicado en el Anuario de Derecho penal, de Lima, 1999-2002, págs. 201-244, y el Anuario de la Facultad de Ciencias Jurídicas de la Universidad de Antofagasta, 2000, págs. 127-172.

4. En todo caso, de esos signos dimos cuenta en "Una especial versión del autoritarismo penal en sus rasgos fundamentales: la «doctrina» de la seguridad ciudadana”, artículo publicado en la Revista brasileira de ciências criminais, de São Paulo, año 11, enero-marzo de 2003, págs. 66-78, adelantado en Gaceta Jurídica, de Santiago de Chile, número 265, julio de 2002, págs. 7-17. Esta ideología, continuadora de la seguridad nacional y vástago de idéntica inspiración política, sigue hasta el presente inspirando las modificaciones del Código penal y las leyes especiales, sobre todo en asuntos de estupefacientes, terrorismo, control de armas, delincuencia juvenil, patrimonial y sexual.

Revista de Ciencias Sociales - Número 68 (2016) - Universidad de Valparáíso - ISSN 0716-7725-Valparáíso, Chile 
sopesamos en toda su dimensión la actualidad del enunciado empírico según el cual si algo anda mal, puede volverse todavía peor.

La reforma de 1999, quién sabe si precisamente por ser fruto de la casualidad — "la nobleza más antigua del mundo" — y no de un principio definido acerca de lo que había que hacer, tuvo bondades innegables que modernizaron las principales especies delictuosas de esta categoría ${ }^{6}$. Mejoró la violación al precisar la acción típica, extender el círculo de sujetos pasivos, revertir la situación de los enajenados, impedidos hasta ese punto por la ley penal de mantener relaciones sexuales, y acordar un tratamiento diferenciado al ataque carnal del marido contra la mujer (artículos 361, 362 y 369 del Código penal). Se actualizó el delito de estupro, ahora cifrado en el concúbito prevaliéndose el autor de una relación o situación disminuida de la víctima menor de edad (artículo 363). En los abusos sexuales se buscó concretar la acción típica, distinguir la situación de adultos, adolescentes y niños según su correlativa capacidad para consentir o, al revés, oponerse a la actuación ajena, y separar de la férula del tipo las injerencias insignificantes (artículos 366, 366 bis y 366 ter). En fin, fue acertada la decisión de disgregar la corrupción del favorecimiento de la prostitución de menores, especificando en cuatro modalidades alternativas una acción hasta ese instante peligrosamente indeterminada y eliminando de los elementos de la figura la habitualidad, propia de los tipos naturalistas de autor.

Claro está que la reforma adoleció de ripios técnicos que empobrecieron los avances y, en algunos casos, descalabraron su orientación teleológica. Discutible y mal ejecutada gramaticalmente resultó la inclusión de la cópula oral como hipótesis equivalente a la vaginal y anal en la violación y el estupro, paralelismo desmentido por

5. Pues "libera las cosas del yugo de la finalidad". NIETZSCHE, Friedrich: Así hablaba Zaratustra. En: Obras inmortales, 4 vols, Edicomunicación, Barcelona, 2003, t. II, traducción de Enrique Eidelstein, Miguel Ángel Garrido y Carlos Palazón, pág. 614 .

6. "Contrariamente a lo que podría pensarse, este cambio tan significativo es más producto del azar que del propósito de abordar en forma orgánica este sector del ordenamiento penal”. RODRÍGUEZ COLLAO, Luis: Delitos sexuales, Editorial Jurídica de Chile, Santiago de Chile, $2^{\text {a }}$ ed., actualizada, 2014, pág. 95.

Facultad de Derecho y Ciencias Sociales - Universidad de Valparaíso - Chile 
la misma reforma, en flagrante antinomia lógica y axiológica, con la redacción que dio a la violación seguida de homicidio (artículo 372 bis). La imprecisión perjudicó por partida doble las condiciones del archivo de los antecedentes y la consiguiente extinción de la responsabilidad criminal del hechor, en los casos de violación o abuso sexual ocurridos en el matrimonio o la pareja extramatrimonial (art. 369), sea por el empleo de la voz "convivientes" para aludir a los miembros de la última ${ }^{7}$, sea por suponer en las formas no violentas de estos delitos una gravedad que no pueden alcanzar. Subsistió el anacronismo del estupro fraudulento, al que se describió mediante una fórmula integrada por elementos antagónicos, engaño y abuso. Las acciones sexuales fueron definidas con un idem per idem — "acción

7. La impropiedad de la expresión para mentar el concubinato y, sobre todo, la falta de regulación civil de la pareja no matrimonial, redundarían en serias dificultades para la jurisprudencia a la hora de fijar los requisitos del borroso concepto, con lo que queremos decir que los jueces se sienten invitados, no a aplicarlo a un supuesto fáctico, porque la ley tampoco define esta convivencia, sino a determinarlo normativamente. Véase TALADRIZ EGUILUZ, María José: "Decisiones judiciales en el ámbito penal acerca del concepto «convivencia»", en la Revista de Ciencias Penales, cit., volumen XLI, número 4, 2014, págs. 79-101. Por lo demás, el Tribunal Constitucional chileno, muy poco respetuoso del principio de legalidad y los demás axiomas del Derecho penal liberal, había declarado el concepto conforme con la Constitución de 1980 en su fallo de 5 de agosto de 2010, analizado últimamente por GONZÁLEZ LILLO, Diego Antonio: "El delito de parricidio: consideraciones críticas sobre sus últimas reformas”, en la revista electrónica Política criminal, de Santiago de Chile, vol. 10, número 19, julio de 2015, cfr. págs. (192-233) [disponible en internet, http://www.politicacriminal.cl/Vol_10/n_19/Vol10N19A7.pdf] 208-2011. Recién el 21 de abril de 2015 se dicta la Ley número 20.830, que crea el acuerdo de unión civil, llamando a sus partes "convivientes civiles" y ordenando que las referencias legales y reglamentarias existentes a los convivientes a secas, ya numerosas dentro y fuera del Código penal, "serán igualmente aplicables a los convivientes civiles" (art. 24). Así y todo, dejó abierta la cuestión de si las referencias legales a los convivientes civiles, como las que ella misma introdujo en varios artículos del Código penal, comprenden la convivencia marital no formalizada en los términos del artículo $1^{\circ}$ de la propia Ley y, al revés, la de si las disposiciones que continúan mencionando sólo esta última, como los artículos 390, sobre parricidio, y 369 del Código, hay que entenderlas en sentido amplio o ceñidas únicamente a la nueva convivencia civil, con el consiguiente perjuicio de la pareja que convive maritalmente sin mediar contrato alguno.

Revista de Ciencias Sociales - Número 68 (2016) - Universidad de Valparaíso - ISSN 0716-7725-Valparaíso, Chile 
sexual es un acto de significación sexual"- y una exigencia tampoco determinada legalmente, la relevancia de la acción ${ }^{8}$. El resultado típico de la corrupción de menores degradó el delito a uno de peligro abstracto, etc.

Pero los aspectos más inquietantes están en la pica que se clavó en el flanco del objeto de tutela. La Ley 19.617 había aspirado a transformar estos maleficios, convirtiéndolos de lo que eran, unos atentados contra la honestidad, en hechos vejatorios de la libertad sexual. El propósito, empero, no estuvo animado por un principio sintético y, en su debilidad, tendría que lidiar con la oposición de fuerzas ultraconservadoras de ancestral predominio en el país. Los defectos técnicos, debidos a la ausencia del principio unificador, dieron forma a un aparato híbrido, un centauro con torso de libertad sexual (en los ataques contra adultos) y miembros de la vieja honestidad (en los que ofenden a jóvenes e infantes). La mitología fue enriquecida con una pareja de auténticos monstruos. Por una parte, lo que a falta de mejor designación denominamos, según el uso histórico, stuprum cum masculo - acceder carnalmente, con su consentimiento, a un varón mayor de catorce y menor de dieciocho años (artículo 366, rémora de la vieja sodomía) - ; por otra, el galimatías de la trata voluntaria de adultos, que la reforma de 1999 conservó de otra anterior (artículo 367 bis) ${ }^{9}$. El mentís que estos seres fantásticos arrojaron a quemarropa de la aclamada libertad sexual de menores y mayores de edad, es sumamente revelador de las concepciones de las capas dominantes acerca de la posición del individuo en la sociedad y de los prejuicios morales que vierten sobre la comunidad. El estupro de varón aquiescente, que persiste hasta la fecha so pretexto de proteger la indemnidad sexual de los jóvenes adultos, responde a una incoercible aversión por la homosexualidad masculina ${ }^{10}$.

8. Semejantes, BULLEMORE GALLARDO, Vivian, y MACKINNON ROEHRS, John: Curso de Derecho penal, publicados, 3 vols., Lexis Nexis, Santiago de Chile, t. III (Parte especial), 2005, cfr. pág. 198.

9. Introducido por la Ley número 19.409, de 7 de septiembre de 1995, la última de las escasas modificaciones que experimentó el tema desde la entrada en vigor del Código hasta la principal de 1999.

10. Manía que queda de manifiesto en el fallo del Tribunal Constitucional de 4 de enero de 2011, que rechazó el requerimiento de inconstitucionalidad

Facultad de Derecho y Ciencias Sociales - Universidad de Valparaíso - Chile 
A su vez, el castigo de quienes promueven o facilitan la entrada al país o salida de él de personas adultas para que ejerzan la prostitución en Chile o el extranjero, contando el autor con el libre e informado consentimiento de ellas, refleja el afán de castigar la mera inmoralidad ${ }^{11}$. Esta última consideración explica, además, que continuaran tipificados delitos y faltas de escándalo público (artículos 373, 495, número $5^{\circ}$ y $7^{\circ}$, y 496, número $9^{\circ}$ ), y la difusión de pornografía entre adultos (artículo $374)^{12}$, a la que pronto haría escolta la difusión o posesión de pornografía con menores de edad.

presentado por la Defensoría penal pública, avalado por un informe en Derecho que firmamos catorce profesores de Derecho penal. La homofobia, así como el paternalismo de la sentencia, son criticados con sobrada razón, que justifica los duros epítetos de su pliego, por el animador del informe, BASCUÑ̂́N RODRÍGUEZ, Antonio: "La prohibición penal de la homosexualidad masculina juvenil (comentario a la sentencia del Tribunal Constitucional de 4 de enero de 2011, rol No 1683-2010)", en la revista Estudios públicos, de Santiago de Chile, número 124, 2011, págs. 113-137. Que la decisión desconozca al adolescente el derecho al libre desarrollo de su personalidad y cercene su vida privada, como destaca Rodríguez Collao, ob. et ed. cits., cfr. pág. 336, puede que se inserte, en definitiva, en el espíritu que trasuntan las disposiciones de la llamada Constitución política de 1980, principalmente su Parte dogmática. Siendo así, el voto mayoritario del Tribunal habría tan sólo aplicado la Constitución a esta cuestión específica, como viene haciendo en otras muchas, igualmente cardinales - reserva legal, taxatividad, proporcionalidad, culpabilidad — para el Derecho penal liberal, siempre con el mismo resultado, alzaprimar las relaciones de poder. De esta Carta otorgada por el régimen militar, que el sistema político y judicial chileno considera vigente, así como de su trasfondo ideológico, nos explayamos en nuestro antiguo trabajo "Relaciones del Derecho penal con el Derecho constitucional, y su concreción en la Constitución política chilena (1980)", en el Anuario de Filosofía Jurídica y Social, publicación de la Sociedad Chilena de Filosofía Jurídica y Social, Edeval, Valparaíso, número 12, 1994, págs. 165-199. Sobre la jurisprudencia del Tribunal Constitucional en asuntos penales discurre VAN WEEZEL DE LA CRUZ, Alex: La garantía de tipicidad en la jurisprudencia del Tribunal Constitucional, Abeledo-Perrot, Santiago de Chile, 2011.

11. Véase nuestro artículo "La trata de personas y el problema de su bien jurídico", en la Revista procesal penal, de Santiago de Chile, número 62, agosto de 2007, págs. 9-19, con versión portuguesa, por Nuno Brandão, "O tráfico de pessoas e o problema do seu bem jurídico", en la Revista Portuguesa de Ciência Criminal, Coimbra, año 18, número 4, octubre-diciembre de 2008, págs. 447-464.

12. La Ley número 19.846, de 4 de enero de 2003, sobre Calificación de la producción cinematográfica, permitirá la exhibición pública de filmes pornográficos, previa calificación del Consejo respectivo, en salas especiales, registradas

Revista de Ciencias Sociales - Número 68 (2016) - Universidad de Valparáíso - ISSN 0716-7725-Valparaíso, Chile 
No sorprende, pues, que el juicio de la doctrina chilena sobre la obra de 1999 fuese incluso más demoledor que las censuras que personalmente nos mereció a poco andar su vigencia. Muchos estudiosos llegarían a la conclusión de que no significó un cambio substancial del sistema de estos delitos, que se mantuvo subyugados a una mentalidad que privilegia veladas exigencias moralizantes como presupuesto del ejercicio de la libertad sexual de las personas ${ }^{13}$.

\section{La incontinencia legislativa de los años sucesivos}

El desvelo reformador reaparece en 2001 y continúa hasta nuestros días en una plétora de modificaciones, todas de bulto. En el arco de catorce años se ha aprobado la friolera de once leyes, número que se agiganta considerando que algunas contienen múltiples innovaciones que embisten contra los delitos del grupo, añaden otros y alteran las disposiciones comunes a todos ellos. Daremos a continuación sinóptica nota de los cambios más importantes, con las consecuencias que aparejaron al conjunto.

en el municipio respectivo, o mediante la venta o arriendo de las cintas para exhibición privada. Teniendo en cuenta que los «cines X» habían perdido importancia debido a internet, la que pronto arruinaría también al comercio establecido de alquiler de vídeos, el gesto del legislador tuvo visos de saludo ceremonial.

13. Con matices, se pronunciarían así RODRÍGUEZ COLLAO, Luis, ob. et ed. cits., cfr. págs. 97-98; BASCUÑ́́N RODRÍGUEZ, Antonio: “La inconsistencia del Derecho penal sexual moderno”. En: Mañalich Raffo, Juan Pablo: La ciencia penal en la Universidad de Chile. Libro homenaje a los profesores del Departamento de Ciencias penales de la Facultad de Derecho de la Universidad de Chile, Santiago de Chile, 2013, cfr. pág. (405-433) 423; HORVITZ LENNON, María Inés: "Delitos sexuales, libertad personal y protección de la moral colectiva". En: Apuntes de Derecho, Universidad Diego Portales, Santiago de Chile, número 3, 1998, cfr. pág. 13, y MALDONADO FUENTES, Francisco: "Tratamiento de la nueva regulación de delitos sexuales", en el volumen Problemas actuales de Derecho penal, Universidad Católica de Temuco, 2003, cfr. págs. (227-265) 241, y el Complemento del autor del capítulo respectivo de GARRIDO MONTT, Mario: Derecho penal, publicados, 4 vols., Editorial Jurídica de Chile, Santiago de Chile, t. III (Parte especial), $3^{\text {a }}$ ed., actualizada, 2007, cfr. pág. 329.

Facultad de Derecho y Ciencias Sociales - Universidad de Valparaíso - Chile 
La más veloz llegó con la Ley número 19.734, de 5 de junio de 2001. Sus disposiciones suprimieron la pena de muerte del Derecho penal común chileno, reemplazándola por una agravación del presidio perpetuo a que se denominó presidio perpetuo "calificado". Sin embargo, la iniciativa no resolvió la manifiesta antinomia existente en el delito de violación con homicidio, que en la versión de 1999 había perjudicado la situación de la mujer y, como se dijo, anulado la pretensa equivalencia de las cópulas vaginal, anal y oral en el artículo $361^{14}$. Esta situación se mantendrá hasta la reforma de 2004, que simplificó la violación con homicidio, aunque preservando como respuesta a la brutalidad del delito la inhumana sanción "abolicionista". Por su parte, el 31 de junio de 2002 la Ley número 19.806, que adecua el sistema legal chileno al Código procesal penal, complementa el anticuado delito de difusión de pornografía ordenando la destrucción de los productos decomisados. Fue una solución técnicamente necesaria para el cumplimiento cabal de la pena de comiso, pero también una anticipación de lo que acaecería en el régimen penal de la pornografía.

Mas no nos precipitemos, que esta trayectoria legislativa antes semeja una sucesión interrumpida, como el delito continuado, que una operación racional y sistemáticamente proseguida de política legislativa. En 2003 se dicta la ley sobre Calificación de la producción cinematográfica ${ }^{15}$. Ésta eliminó de la corrupción de menores (artículo 366 quater, inciso segundo, del Código) la modalidad de emplear a menores de doce años en la producción de material pornográfico, a cambio de lo cual tipifica en su propio plan (artículo 30) los delitos de participar en la producción de material pornográfico en cuya elaboración hayan sido utilizados menores de dieciocho años, y comercializarlo, importarlo, distribuirlo o exhibirlo. Se anuló formalmente, en este aspecto, la libertad sexual de los jóvenes adultos, aumentó las penas y disolvió la distinción de los conceptos de autor y partícipe, perdida tras

14. La capital sólo era procedente si se había violado vaginalmente a una mujer o analmente a un hombre. En cambio, la violación anal u oral de la fémina, seguida de su homicidio, era castigada con la pena de presidio mayor en su grado máximo a presidio perpetuo.

15. Sus datos quedaron consignados supra, nota 12.

Revista de Ciencias Sociales - Número 68 (2016) - Universidad de Valparáíso - ISSN 0716-7725-Valparaíso, Chile 
la generalizadora cláusula unitaria "el que participe". Como sea, esta pareja de infracciones ingresaría al Código ulteriormente ampliada un año más tarde, no sin que primero volviese a anunciarse el prurito de blindar la situación de los jóvenes merced a la fractura de los límites y una relajación de las condiciones de ejercicio del ius puniendi. La Ley número 19.874, de 13 de mayo de 2003, que viene a ser la cuarta desde el itinerario iniciado en 1999, convirtió en pública la acción derivada de violación, estupro, abusos sexuales y corrupción tratándose de víctimas menores de edad, sin distinción de niños y adolescentes ${ }^{16}$.

Los daños causados eran aún contenidos y distaban de ser el desastre del sistema. Pero el temido desenlace no se hizo esperar. La Ley número 19.927, de 14 de enero de 2004, tomó sobre sí la ímproba tarea de desarticular los delitos, endurecer sus penas, desleír los méritos de la reforma de 1999 e inaugurar una cabalgata represiva de inaudito desprecio por la libertad humana.

Por lo pronto, se reescribió el epígrafe del título VII, libro II, donde el Código aloja los maleficios, bautizándolos como ofensivos de la "integridad sexual". El vaporoso concepto venía a pedir de boca para extender las figuras, subir las penalidades y dilatar las atribuciones de la policía. De hecho, el resultado de la operación consistió en mutilar la autodeterminación sexual de los jóvenes, invadir la intimidad de sus mayores, ensañarse con la soledad algunos, entrometerse en la fantasía de otros y, en definitiva, raer la racionalidad del aparato punitivo, desproporcionándolo y desbocándolo. La mudanza anunciada en el objeto jurídico es ilustrativa del carácter que se quiso infundir a este segmento del Código. En efecto, tomada literalmente, la expresión integridad sexual carece de sentido. Nadie, ni siquiera la persona más experimentada en estas lides, puede llamarse íntegro. La complejidad del impulso sexual hace quimérico que se reúna alguna vez, con todas sus partes bien ensambladas, en la economía psíquica y social de una

16. Hasta ese momento, tales delitos eran de acción mixta o dependiente de instancia particular, como siguen siéndolo si el ofendido es adulto (artículo 369). Sin embargo, aun así podía el ministerio público proceder de oficio cuando la víctima, por su edad o estado mental, no podía denunciar el hecho o no tenía representantes en posición de hacerlo. En el fondo, la modificación permitió que cualquiera se interese en la situación del menor llevando el asunto a la justicia.

Facultad de Derecho y Ciencias Sociales - Universidad de Valparaíso - Chile 
personalidad; dicho de otra manera, no existe ni presumiblemente habrá nunca un ser humano que esté sexualmente completo ${ }^{17}$. Por otra parte, como la integridad sexual tampoco es sinónimo de salud, concepto médicamente distinto y jurídicamente ajeno al resultado típico de estos hechos, para la apreciación dogmática sólo resta la acepción de rectitud, probidad y, sobre todo, pureza congruente a la integridad, por más que semejantes cualidades superen las de la antigua honestidad y sean incluso más exigentes que el pudor sexual. A este palenque de pureza con que se circundó la libertad sexual de los chilenos, obedecen las novedades que la Ley 19.927 descargó sobre el Código ${ }^{18}$.

La cuestión de los menores fue la tónica. Se elevó de doce a catorce años el umbral biológico para prestar consentimiento válido a las acciones descriptas en los núcleos de la violación, el estupro, los abusos sexuales y la corrupción. Tal cercenamiento de la libertad de los jóvenes asume ribetes preocupantes si se toma en cuenta que la cláusula de atipicidad que ampara el juego sexual entre adolescentes, prevista extra muros del Código, exige que la diferencia de edad entre ellos no exceda de dos años, tratándose del coito heterosexual, y tres años para el concúbito homosexual, los escarceos no genitales, la contemplación del cuerpo y las representaciones erógenas. La estrechez del margen,

17. Los artistas son conscientes de esta limitación, inevitable dada la naturaleza humana. Piénsese en las contrafiguras del crápula Juan Tenorio y su casta prometida, Inés de Ulloa, en el drama de Zorrilla.

18. Los críticos no hacen hincapié en este medular aspecto. Véanse, por ejemplo, BASCUÑ́́N RODRÍGUEZ, Antonio: La inconsistencia del Derecho penal sexual moderno, cit., págs. 424-425, el que, empero, con razón destaca que esta ley fue el fracaso estrepitoso de la estrategia reductora insinuada en 1999, y RODRÍGUEZ COLLAO, Luis, ob. et ed. cits., págs. 102-104 y 132-135. Interesante es lo que anota el último: con esta reforma arremetió una cultura francamente represiva de la sexualidad humana "que siempre ha estado latente en nuestra sociedad y que ahora parece haber emergido con una fuerza sencillamente demoledora" (págs. 134 y 177). Terminante, en cambio, en España, Díez Ripollés, quien habla de una "libertad sexual asediada" por la voluntad de "protección del integrismo sexual", que reemplaza la concepción positiva del ejercicio libre de la sexualidad por otra mojigata y prejuiciosa, disfrazada con la "nueva palabrita mágica" de integridad sexual. DÍEZ RIPOLLÉS, José Luis: Delitos y penas en España, Catarata, Madrid, 2015, págs. 125 y 129.

Revista de Ciencias Sociales - Número 68 (2016) - Universidad de Valparáíso - ISSN 0716-7725-Valparáiso, Chile 
combinada con la decisión de infantilizar la etapa final de la puericia, negó conscientemente a muchachos y muchachas menores de catorce años la factibilidad de trabar relaciones eróticas con no pocos jóvenes adultos, pese a la frecuencia del hecho en el país ${ }^{19}$. En seguida, se impuso una misma pena, presidio menor en su grado máximo a presidio mayor en su grado mínimo, aumentada respecto de la original e idéntica a la del estupro - asimismo acrecentada por la reforma-, al abuso sexual cometido en la persona de un menor de catorce años, sin diferenciar si el autor se valió de violencia o intimidación o actuó con su aquiescencia (artículo 366 bis). Luego, se restituyó al Código el delito de participar en la producción de material pornográfico elaborado con el empleo de menores (artículo 366 quinquies), de nuevo sin distinguir si los protagonistas tienen más o menos de catorce años de $\operatorname{edad}^{20} \mathrm{y}$, lo que es aún más grave, con la añadidura de una interpretación auténtica contextual que declara pornografía tanto la realización efectiva de actividades sexuales explícitas como la sólo simulada ${ }^{21}$. Igual concepto se hizo aplicable a la difusión de pornografía juvenil, que reingresa al

19. Artículo $4^{\circ}$ de la Ley número 20.084, de 7 de diciembre de 2005, sobre responsabilidad penal de los adolescentes. Bien se ha escrito que la brevedad del lapso proviene de la reinvención de una moral sexual secularizada que, bajo los nombres de integridad e indemnidad sexuales, presupone un perjuicio en el desarrollo normal del menor de catorce por la sola circunstancia de mediar una diferencia superior a la establecida por la ley. Cfr. OXMAN VILCHES, Nicolás: "Consideraciones críticas en torno al artículo $4^{\circ}$ de la Ley de Responsabilidad Penal Juvenil”. En: Fernández Cruz, José Ángel: Estudios de Ciencias penales. Hacia una racionalización del Derecho penal, Legalpublishing, Santiago de Chile, 2008, págs. (89-108) 93-94.

20. La idea era vedar completamente el consentimiento lícito de los jóvenes adultos, según observa COX LEIXELARD, Juan Pablo: "Los delitos de producción, adquisición y tenencia maliciosa de material pornográfico como figuras expansivas del Derecho penal”. En: Revista de Derecho, Pontificia Universidad Católica de Valparaíso, número XXVI, primer semestre de 2005, cfr. pág. (145-154) 152.

21. Únicamente una interpretación teleológica por el método y restrictiva en el resultado, permite concluir que la pornografía virtual y la pseudo pornografía permanecen al margen del tipo de lo injusto de este delito, que demanda utilizar a los jóvenes, por tanto, usarlos en carne y hueso. Así, RODRÍGUEZ COLLAO, Luis, ob. et ed. cits., cfr. págs. 319-320.

Facultad de Derecho y Ciencias Sociales - Universidad de Valparaíso - Chile 
Código con penalidad incrementada, y al inédito delito de adquirirla o almacenarla (artículo 374 bis), hipótesis desprovista de objeto de tutela, permanente por su relación con el tiempo en la modalidad de almacenar e interesada en perseguir criminalmente el mundo imaginario del autor en vez de proteger la libertad sexual de nadie ${ }^{22}$. Para completar su cuadro

22. Se comprenderá que en estas condiciones la doctrina lo critique ásperamente.

Véanse MAYER LUX, Laura: "Almacenamiento de pornografía en cuya elaboración se utilice a menores de dieciocho años: un delito asistemático, ilegítimo e inútil”. En: Política Criminal, cit., vol. 9, número 17, julio de 2014, págs. (25-57) 40 y 47. La autora se esmera por rescatar el carácter instantáneo de la ejecución de la actividad de almacenamiento (cfr. págs. 31-33), de suerte marginarla de la imprescriptibilidad ingénita a los tortuosos delitos “de posesión”. Desgraciadamente, a la acción de almacenar pertenece no sólo la producción, sino también el mantenimiento de un resultado antijurídico que se prolongará mientras el sujeto conserve el material acopiado o éste sea destruido o incautado. Acerca del carácter permanente del resultado de los delitos de posesión en general y del almacenamiento de pornografía en particular, COX LEIXELARD, Juan Pablo: Delitos de posesión. Bases para una dogmática, Editorial B. de F., Montevideo-Buenos Aires, 2012, cfr. págs. 223 y 235.

De delito contra la moral sexual califica al artículo 374 bis BULLEMORE GALLARDO, Vivian: Derecho penal. Tratado de jurisprudencia y doctrina, 2 vols., Thomson Reuters, Santiago de Chile, 2011, t. I, cfr. pág. 418; por un ataque a la intimidad sexual del menor se pronuncia circunspectamente RODRÍGUEZ COLLAO, Luis: "Criterios de agravación de la pena en los delitos de producción, difusión y almacenamiento de pornografía infantil”. En: Revista de Derecho, Universidad Austral de Chile, Valdivia, vol. XXVI, número 1, julio de 2013, pág. (145-166) 152. La zarpa de Derecho penal de autor se reconoce en haberse desoído durante el proceso legislativo la recomendación de poner como requisito del tipo que el autor adquiera o almacene la pornografía con la finalidad de difundirla entre terceros. Cfr. POLITOFF LIFSCHITZ, Sergio, MATUS ACUÑA, Jean Pierre, y RAMÍREZ GUZMÁN, María Cecilia: Lecciones de Derecho penal chileno, Parte especial, Editorial Jurídica de Chile, Santiago de Chile, $2^{\mathrm{a}}$ ed., actualizada, 2004, pág. 287. Recomendó calurosamente incluirlo, para no incurrir en "notorias contradicciones con las exigencias del principio de dañosidad social de la conducta en cuanto limitador del ius puniendi del Estado", KÜNSEMÜLLER LOEBENFELDER, Carlos: "Delitos de pornografía infantil (modificaciones legales anunciadas y problemas «ad portas»)", en Gaceta Jurídica, de Santiago de Chile, número 273, marzo de 2003, pág. (7-13) 11. En España se ha postulado derechamente la descriminalización de la ponzoñosa especie. Cfr. ESQUINAS VALVERDE, Patricia: "El tipo de mera posesión de pornografía infantil en el Código penal español (art. 189.2): razones para su destipificación”, en Revista de Derecho penal y Criminología, Madrid, $2^{a}$ época, número 18, julio de 2006, págs. 171 228, especialmente 181-182 y 186-187.

Revista de Ciencias Sociales - Número 68 (2016) - Universidad de Valparáíso - ISSN 0716-7725-Valparaíso, Chile 
infantil, la Ley 19.927 mete al Código el delito de trato carnal por precio con adolescentes (artículo 367 ter). De haber algún bien individual amenazado por la prostitución, está en posición de vulnerarlo quien la favorece "para satisfacer los deseos de otro", que es otro delito (el del artículo 367). Pero la situación de quien busca mediante un precio satisfacer deseos propios presenta a lo menos dos características que aconsejarían librarlo de la Justicia penal. Él actúa con el consentimiento libre del joven, sin valerse de los medios ni aprovechar las relaciones o situaciones típicas de la violación y el estupro. Esto basta para descartar que ofenda bien jurídico alguno del adolescente, salvo que entendamos que éste carece de libertad sexual ${ }^{23}$. Además, y en contra de un uso lingüístico tan difuso como equivocado, el autor no es un "cliente" 24 . Esta palabra mercantiliza una acción que nada tiene que ver con utilizar asiduamente los servicios de una empresa, tienda o un profesional. Tampoco es un "servicio" lo que el joven concede, ni siquiera en la acepción económica del término — prestaciones humanas inmateriales que satisfacen necesidades sociales-, grato a un legislador que se ha hecho el hábito de obscurecer los conceptos jurídico-penales con vocablos financieros y comerciales. En verdad, estamos ante un hombre o una mujer que buscan el amor mercenario por una miríada de razones, algunas censurables, otras comprensibles y hasta disculpables humanamente hablando (soledad, discapacidad, fealdad, vejez, etc.).

La reforma de 2004 estableció, además, una variedad hiperagravada del delito de abusos sexuales: la introducción de objetos o animales en las cavidades vaginal, anal y bucal, cuya pena es la misma

23. Como en el texto, RODRÍGUEZ COLLAO, Luis: Delitos sexuales, ob. et ed. cits., cfr. pág. 302, y CARNEVALI RODRÍGUEZ, Raúl: "Algunas precisiones respecto de los delitos de producción de material pornográfico infantil, de favorecimiento a la prostitución de menores y de obtención de servicios sexuales”, Informe en Derecho, número 2, Defensoría Penal Pública, Santiago de Chile, 2012, cfr. págs. 14-15.

24. De lo extendido del término en los países que tipifican el hecho ministra un amplio panorama comparativo RAMÍREZ GUZMÁN, María Cecilia: La regulación penal de la prostitución infantil. Derecho internacional, de la Unión Europea y Comparado. Especial referencia a los sujetos involucrados, Dictus Publishing, Saarbrücken, 2014, cfr. págs. 68-70, 80 y 87-90.

Facultad de Derecho y Ciencias Sociales - Universidad de Valparaíso - Chile 
de la violación y el estupro (artículo 365 bis). El despropósito trajo consigo previsibles dificultades teóricas y prácticas. Puesto que la invasión corpórea resulta más grave cuando es carnal que si se realiza por medio de objetos "de cualquier índole" —que así reza la letra del precepto-, algunos tribunales cederán a la tentación de colmar las insuficiencias del tipo acudiendo a una integración analógica con arreglo a la cual los dedos de la mano serían objetos ${ }^{25}$. Y como la punición parece inigualable a la del coito forzado, parte de la doctrina propone reformular el sentido teleológico de la disposición haciéndola pluriofensiva, es decir, que la acción tendría que causar un peligro para la salud física o integridad corporal de la víctima ${ }^{26}$. Siendo así, mejor hubiera sido recoger el desvalor particular del acto a través de la agravante común de ensañamiento (artículo 12 , circunstancia $4^{a}$ ) y, en su caso, el delito de aplicación de tormentos a detenidos (artículo 150 A $)^{27}$. Por último, aumentaron las penas privativas de la libertad de todos los delitos, se agregó una pena de interdicción para los cometidos contra menores de edad —inhabilitación absoluta temporal para cargos, empleos, oficios y profesiones ejercidos en ámbitos educacionales o que supongan una relación directa y habitual con menores ${ }^{28}$ - y habilitó

25. Véase la completa crítica de FERNÁNDEZ CRUZ, José Ángel: "Los delitos de violación y estupro del artículo 365 bis del Código penal: una racionalización desde el mandato de lex stricta y el principio de lesividad. Especial referencia a la introducción de dedos u otras partes del cuerpo", en la revista Ius et Praxis, Talca, año 13, número 2, 2007, págs. (105-135) 117-123.

26. Ídem, cfr. pág. 124.

27. Dicho sea por inciso, precisamente el recuerdo de la tortura explica la mención de los animales en estos abusos sexuales, referencia sin duda "excéntrica", en sentir de RODRÍGUEZ COLLAO, Luis: Delitos sexuales, ob. et ed. cits., cfr. pág. 279, sin el dato histórico. Se sabe que la dictadura que gobernó el país de 1973 a 1990 atormentó en sus mazmorras a mujeres detenidas metiéndoles roedores y otras alimañas en sus partes pudendas. Cfr. el Informe de la Comisión Nacional sobre Prisión Política y Tortura, Santiago de Chile, 2005, págs. 225-257.

28. De esta medida de incapacitación, sus problemas y crítica nos ocupamos en nuestro libro La pena y la extinción de la responsabilidad penal. Primera parte: penas y medidas de seguridad; sistemas penales; clasificaciones de las penas; las penas en particular, Legalpublishing, Santiago de Chile, 2008, pág. 301.

Revista de Ciencias Sociales - Número 68 (2016) - Universidad de Valparáíso - ISSN 0716-7725-Valparaíso, Chile 
procedimientos subrepticios para la investigación del tráfico de pornografía y prostitución (artículo 369 ter: agentes encubiertos).

La cosa no paró aquí. En el lustro 2007-2014 se dicta seis nuevas leyes, menos ricas en contenido que la de 2004, pero a las que tampoco se puede considerar decorativas del panorama que ésta pergeñó. La número 20.207, de 31 de agosto de 2007, fija como día de inicio de la prescripción de la acción penal de los delitos de violación, estupro, abusos sexuales y corrupción cometidos contra menores, aquel en que la víctima cumpla dieciocho años de edad. El objetivo de extender el plazo en obsequio de los intereses y la voluntad del afectado choca frontalmente con el sistema de la prescripción del Código ${ }^{29}$, lo que tenía que traducirse en un caudal de logogrifos (duplicidad o unidad del plazo según el sujeto que ejerce la acción, transformación o conservación de la naturaleza procesal de ésta, y otros ${ }^{30}$ ) y, sobre todo, denota una vez más la vehemente actitud de rebajar el derecho de castigar, limitado por definición, a nudo poder penal ${ }^{31}$. En esta línea se inscribe la Ley número 20.480, de 18 de diciembre de 2010, que derogó la posibilidad de

29. Según el artículo 101, la prescripción penal corre a favor y en contra de toda clase de personas. Compárese GUZMÁN DALBORA, José Luis: "De la extinción de la responsabilidad penal”. En: Politoff Lifschitz, Sergio, y Ortiz Quiroga, Luis: Texto y comentario del Código penal chileno, publicado, 1 vol., Editorial Jurídica de Chile, Santiago de Chile, 2002, págs. (433-487) 481.

30. Analíticamente examinados por OLIVER CALDERÓN, Guillermo, en varios estudios, de los que citamos tan sólo "La aplicación temporal de la nueva regla del cómputo del plazo de prescripción de la acción penal en delitos sexuales con víctimas menores de edad". En: Revista de Derecho, Pontificia Universidad Católica de Valparaíso, cit., número XXIX, $2^{\circ}$ Semestre de 2007, págs. 257-266.

31. Siquiera en un contexto apenas simbólico, ya que con plazos tan largos será vano o dificilísimo el hallazgo de la prueba. Cfr. PEÑA WASAFF, Silvia, y SANTIBÁÑEZ TORRES, María Elena: "La prescripción de delitos sexuales contra menores de edad. (Modificaciones introducidas por la Ley No 20.207, de 31 de agosto de 2007)”. En: Microjuris, enero de 2008, cfr. pág. 9. Una juiciosa crítica de la disposición en CABEZAS CABEZAS, Carlos: "Prescripción de los delitos contra la indemnidad y libertad sexual de los menores de edad: problemas aplicativos del artículo 369 quáter del Código penal”. En: Política Criminal, cit., vol. 8, número 16, diciembre de 2013, págs. 386-407.

Facultad de Derecho y Ciencias Sociales - Universidad de Valparaíso - Chile 
sobreseer definitivamente los procesos por violaciones o abusos sexuales no violentos del marido o concubinario contra su mujer y, en compensación de la pérdida de la eximente, añadió como agravantes específicas la alevosía y la pluralidad de malhechores, de muy dudosa aplicabilidad en estos delitos, la primera por ser inherente a los de carácter violento o abusivo, la segunda porque empeoraría la situación de los coautores, cuya coparticipación es indispensable para la imputación recíproca de responsabilidades ${ }^{32}$. Menos de un año después, el 8 de abril de 2011, la Ley número 20.507 traslada la trata consentida de adultos al artículo 411 ter, pese que la propia modificación tipificó el tráfico de personas (artículo 411 quáter), delito que, en consonancia con el Derecho internacional, sí vincula los medios de ejecución, presupone violentar, engañar o abusar del paciente y puede tener por objeto la explotación sexual. Mientras el tráfico lesiona la libertad ambulatoria y pone en concreto peligro la libertad sexual de las víctimas, la trata, en que no las hay, parece que ofende las ideas morales del legislador.

La triada postrema de modificaciones tiene de nuevo como polos a los menores y, principalmente, a sus odiados corruptores. La Ley número 20.256 aporta la novedad de la corrupción telemática (artículo 366 quáter), pero con una curiosa indicación, que ella puede ser cometida “a distancia”33. La Ley número 20.594, de 19 de octubre de 2012, impone la pena de inhabilitación absoluta perpetua para trabajar en contacto con menores a los reos de delitos graves contra éstos (artículos 21 y 372), crea una sección especial en el Registro de condenas para anotar a los condenados perpetua o temporalmente a la interdicción y obliga a las instituciones o individuos que requieran contratar a personas para funciones que impliquen una relación directa con menores de dieciocho años, a que soliciten previamente al Registro la información de si el

32. Cfr. RODRÍGUEZ COLLAO, Luis: "Criterios de agravación de la pena en los delitos de producción, difusión y almacenamiento de pornografía infantil”, cit., págs. 156-158.

33. El empleo de técnicas de telecomunicación e informática a la transmisión de información computarizada opera siempre a distancia entre emisor y receptor, no vis a vis.

Revista de Ciencias Sociales - Número 68 (2016) - Universidad de Valparáíso - ISSN 0716-7725-Valparáís, Chile 
candidato aparece o no en sílabo. Con esto, simples particulares pasan a ser corresponsables de la ejecución de una pena pública, pero en el marco de una potestad, un poder-deber, porque la ley otorga a cualquiera persona natural o jurídica el derecho de pedir la información, bastando que se identifique; el acceso al registro es telemático, como telemática es esta pena infamante ${ }^{34}$. A la infamia, la Ley número 20.685, de 20 de agosto de 2013, la última de este repertorio, sumó el ostracismo social y la incapacitación del condenado. Quien hubiere satisfecho la pena privativa de la libertad podrá solicitar su rehabilitación sólo después de transcurridos diez años del cumplimiento, que es asimismo la duración máxima de la inhabilitación temporal para trabajar en contacto con menores. El reo de violación o abuso sexual de menores de catorce años, producción de pornografía y favorecimiento de la prostitución de menores, necesitará enterar dos tercios de la pena en la cárcel para solicitar la libertad condicional, no la mitad, que es la regla general. Su posición fue equiparada a los reos de parricidio, asesinato y otros hechos de sangre, en demostración de que para el legislador da exactamente igual abusar de un niño o prostituir a un adolescente, que asesinarlos.

\section{El Anteproyecto de Código penal de 2005 y el Proyecto de 2014}

En el último decenio readquirió vigor el empeño de efectuar una reforma total del Código de 1875, que había quedado paralizado después del Proyecto de $1946^{35}$.

El Anteproyecto de nuevo Código penal (2005) y el Proyecto que establece un nuevo Código penal (2014), nativos de iniciativas gubernamentales y del trabajo técnico de sendas comisiones de

34. Poco habrá de temer quien utilice la información para fines distintos del autorizado por la ley, una multa impuesta por el juez de policía local, nombre que reciben en Chile los tribunales correccionales.

35. Acerca de éste y los Proyectos Erazo-Fontecilla (1929), Ortiz-von Bohlen (1929) y Labatut-Silva (1938), véanse RIVACOBA Y RIVACOBA, Manuel: Evolución histórica del Derecho penal chileno, Edeval, Valparaíso, 1991, págs. 85-107, y MATUS ACUÑA, Jean Pierre: Evolución histórica de la doctrina penal chilena desde 1874 hasta nuestros días, Legalpublishing, Santiago de Chile, 2011, págs. 187-197.

Facultad de Derecho y Ciencias Sociales - Universidad de Valparaíso - Chile 
especialistas, regulan de diferente manera estos delitos, a los que reúnen bajo denominaciones también distintas, "contra la integridad sexual" en el Anteproyecto de 2005 y "contra la libertad sexual" en el Proyecto de $2014^{36}$. Ambos ven la luz en condiciones a nuestro entender poco propicias para la recodificación penal, debido a la pérdida de orientación de los poderes públicos, la ausencia de política criminal en los programas y la acción de los partidos políticos, así como el ambiente de temor a la criminalidad callejera que domina a los espíritus, miedos compartidos que se intenta conjurar mediante la demonización social del delincuente, la exacerbación de las penas y la introducción de excepciones a los principios rectores de los delitos, las reglas que rigen la aplicación de las puniciones y el procedimiento de investigación y juicio ${ }^{37}$. En estas circunstancias, era de esperar que los proyectos codificadores tuviesen limitadas perspectivas de proponer con éxito un verdadero progreso en nuestro tema, o sea, racionalizarlo y humanizarlo, lo que reclama ante todo reobrar sobre los estragos descriptos en el acápite anterior. De hecho, uno y otro preservan la mayoría de los delitos existentes, a los que se mejora en ciertos aspectos técnicos, aumenta o reduce en su cabida, uno los reordena y los dos mantienen bajo la férula de penas de prisión, más severas en el Anteproyecto de 2005 que el Proyecto 2014.

Los delitos del Anteproyecto, en el título V del libro II, son siete: violación (artículos 98 y 99), estupro (artículo 100), abusos sexuales (artículos 101, 102 y 103), corrupción de menores (artículos 104, 105 y 106), favorecimiento de su prostitución (artículo 107), consecución mercenaria de actos de significación sexual (artículo 108) y difusión, adquisición o almacenamiento de pornografía con menores de edad

36. Cfr. Anteproyecto de nuevo Código penal. Texto refundido y sistematizado del articulado aprobado en las deliberaciones de la Comisión Foro Penal del Ministerio de Justicia, desde el 8 de mayo de 2003 hasta el 10 de noviembre de 2005, en Política Criminal, cit., número 1, julio de 2006, págs. 24-26, y Proyecto de ley, iniciado en Mensaje de S. E. el Presidente de la República, que establece un nuevo Código penal, en Revista de Ciencias penales, cit., Sexta Época, volumen XLI, número 2, 2014, págs. (199-358) 272-276 y $318-320$.

37. De todo lo cual nos extendemos en Introduzione: Il Codice penale cileno nel prisma del tempo. En: Fornasari, Gabriele, y Corn, Emanuele: Codice penale della Repubblica del Cile, Cedam, Padova, 2013, págs. IX-XXXIV.

Revista de Ciencias Sociales - Número 68 (2016) - Universidad de Valparáíso - ISSN 0716-7725-Valparáiso, Chile 
(artículo 109). La violación amplía su esfera para castigar a las mujeres ${ }^{38}$. Desaparece el estupro fraudulento, lo que está muy bien, pero se acude a un elemento del juicio cognitivo de difícil determinación ("gran importancia”) al calificar la situación de necesidad o dependencia de la víctima del estupro por prevalimiento. En los abusos sexuales se insiste en la hipótesis agravada de introducción de objetos, además de "otras partes del cuerpo", pero sólo en la vagina o el ano —la llamada cópula "bucal" aparece en la violación y el estupro, como en la ley vigente desde 1999- y el empleo de animales, al que se destina una disposición propia y castiga con pena máxima igual a la violación (artículo 102). El abuso sexual de menores de doce años entraña la misma consecuencia que realizar actos inverecundos ante ellos (artículos 103 y 104); y el empleo de jóvenes en la producción de material pornográfico o el favorecimiento de su prostitución, no distinguen entre adolescentes y niños, siendo la pena de ambos casos idéntica a la del abuso (artículos 106 y 107), aunque mayor que la asignada al trato carnal mercenario. Estos preceptos, pues, prosiguen las líneas generales del Código tras las reformas de 1999 y, sobre todo, 2004. Una contraprueba del especial influjo de la última luce inequívoco en la previsión de la difusión y tenencia de pornografía infantil o adolescente. En todo caso, el Anteproyecto las sanciona con un grado menos, siguiendo un temple general de cierta moderación, que mucha falta hace en esta maltratada materia ${ }^{39}$. También es de celebrar la supresión de la sodomía, el incesto, el escándalo público y la violación con homicidio ${ }^{40}$.

38. Mediante la substantivación del núcleo, no ya acceder carnalmente, sino "acceso carnal", lo que permite castigar al que penetra, pero también al que se hace penetrar por la víctima. Conforme, RODRÍGUEZ COLLAO, Luis: "Sobre la regulación de los delitos contra la integridad sexual en el Anteproyecto de Código penal”. En: Política Criminal, cit., número 1, 2006, pág. (1-19) 10. Sin embargo, esto no es tan claro en el artículo 99, que describe el acceso carnal "a una persona menor de doce años". La preposición a requiere un complemento directo, que pasa a ser aquí el paciente de la acción. No está bien empleada; el substantivo debió de ir seguido por otra preposición, de ("el acceso de"), que hubiera salvado el problema, como en el artículo 98 .

39. La penalidad del delito más grave, la violación de menores de doce años, puede alcanzar quince años, al paso que hoy se empina hasta veinte. Sin embargo, el grado mínimo actual en el artículo 362 del Código, cinco años, es inferior a los diez del artículo 99 del Anteproyecto.

40. Cfr. RODRÍGUEZ COLLAO, Luis: "Sobre la regulación de los delitos contra la integridad sexual en el Anteproyecto de Código penal”, cit., pág. 18.

Facultad de Derecho y Ciencias Sociales - Universidad de Valparaíso - Chile 
El Proyecto de 2014 distribuye la materia en dos secciones bastante distanciadas topográfica y teleológicamente: los "delitos contra la libertad sexual” del libro II, título III (artículos 254-273), y los “delitos contra el orden público” del título XII, el que comprende un parágrafo sobre "exhibicionismo, proxenetismo y prostitución y pornografía infantil y juvenil" (artículos 478-484). La redacción, pesada e inelegante, conspira contra el objetivo de hacer girar los primeros preceptos en torno de la libertad del hombre, sea éste víctima o victimario. Una hierática frase sirve de hilo conductor a los subgrupos de agresión, abuso y atentados sexuales: "constreñir o compeler a otro a tolerar". Extraño al genio de nuestro idioma y a la técnica de los Códigos de la familia hispana, el tosco giro lingüístico cae como una lápida sobre la estructura de los tipos, con el efecto de adelantar la consumación a la fase de tentativa, para colmo duramente castigada, aun si se comete por culpa (artículo 267) ${ }^{41}$. Esto aparte, las palabras "agresión”, "abuso" y "atentado", que aparentan poner énfasis en el menosprecio de la voluntad ajena, en verdad celan exactamente los delitos de siempre: violación, casuísticamente regulada en los artículos 256, 259 y 264; abusos sexuales, que figuran con este nombre, aunque también con los de agresión y atentado, en los artículos 254, 255, 257, 258, 261, 262 y 263, y el estupro (artículo 263), que en este documento presenta la llamativa singularidad de poder perpetrarse en la persona de un adulto si el agente abusa de alguna anomalía no constitutiva de enajenación o trastorno (artículo 260) ${ }^{42}$. El delito de "interacción sexual" luce en el titulillo del artículo 265 referido a menores de doce años, pero el contenido del precepto indica catorce, descuido que deja en la penumbra cuáles jóvenes conservan libertad para ver o escuchar material pornográfico, realizar o presenciar acciones de significación sexual, etc. De nuevo al modo alemán, se declara punible la tentativa de todos

41. También son punibles la conspiración y la proposición de los delitos perpetrados contra menores de edad (artículo 268).

42. Pero cuidado: no constituye anomalía o perturbación mental transitoria, "en el sentido de este artículo, la que pudo ser evitada por quien la padeció". Menuda advertencia en un país caracterizado históricamente por altas cotas de consumo de alcohol, alcoholismo que ha aumentado preocupantemente en todas las capas de la población, niños, jóvenes y adultos, como vía de escape de las condiciones económicas y sociales en que se arrastra la vida los chilenos desde la satrapía cívico-militar.

Revista de Ciencias Sociales - Número 68 (2016) - Universidad de Valparáíso - ISSN 0716-7725-Valparáiso, Chile 
estos delitos (la tentativa de la tentativa, o sea, actos preparatorios). Es agravada específicamente la muerte o las lesiones de la víctima, incluso si estos resultados fueren imputables a imprudencia (artículo 271), dentro de un concurso real que habilita la pena de prisión perpetua (artículo 52) de presentarse alguna agravante adicional (artículo 269). El plazo de prescripción de la acción penal de los hechos contra menores empieza a correr al cumplir éstos la mayoría de edad (artículo 273). Y el perdón del cónyuge o "conviviente" extingue la responsabilidad de su consorte, pero sólo si hacen vida en común (artículo 272).

La cantidad y el casuismo de las disposiciones, que dificultan el manejo del Proyecto ${ }^{43}$, se replican en el título XII. La generosa cobertura que regala el orden público permite rendir homenaje a los sentimientos pudorosos del último aspirante a la codificación. El artículo 478 castiga el exhibicionismo ante adultos, concepto que se extiende al hecho de mostrar o enviar a personas maduras imágenes pornográficas; la pena es tenue, pero puede llegar a tres años de prisión de haber una "molestia masiva”. Tampoco se echa de menos el proxenetismo rufianesco con mayores de dieciocho años (artículo 480). Huelga insistir en que si el primero de estos delitos es anticuado, porque responde a concepciones de medio siglo atrás ${ }^{44}$, el segundo suena todavía más anacrónico, como el hijo que es de los arrestos moralizantes del positivismo criminológico y la mentalidad de súbdito de la época Guillermina, entrometidos en los reclamos legítimos del movimiento abolicionista de los reglamentos de la prostitución ${ }^{45}$. Traen a las mientes el artefacto del poeta Nicanor Parra: "En mi delirio sólo veo catástrofes y fantasías de orden sexual"

43. De agobiante extensión, 658 artículos, más de ciento cincuenta que el Código vigente, doscientos que el peruano (1991) y el doble del boliviano (1997), sólo por mencionar los de nuestros vecinos.

44. Incluso entonces se objetó que el derecho a no ser confrontado involuntariamente con pornografía es una pretensión moral por demás absurda en la sociedad actual, cargada de sexualidad en la vida pública. Cfr. DÍEZ RIPOLLÉS, José Luis: Exhibicionismo, pornografía y otras conductas sexuales provocadoras. (La frontera del Derecho penal sexual), Bosch, Barcelona, 1982, pág. 100.

45. Véase, al respecto, JIMÉNEZ DE ASÚA, Luis: Libertad de amar y derecho a morir. Ensayo de un criminalista sobre eugenesia y eutanasia, Depalma, Buenos Aires, $7^{\mathrm{a}}$ ed., 1984, págs. 86-89.

46. Obras completas \& algo †, 2 vols., Galaxia Gutemberg, Barcelona, 2011, t. I, pág. 371.

Facultad de Derecho y Ciencias Sociales - Universidad de Valparaíso - Chile 


\section{Lineamientos para una racionalización de la materia}

A la espera de que soplen mejores vientos para la recodificación penal, que a nuestro juicio tendrá un fundamento sólido y podrá gozar de estabilidad en el tiempo si es acometida después que Chile se haya dado una verdadera Constitución, deliberada por una asamblea con amplia representación popular, registremos brevemente algunas orientaciones para la reforma preliminar de este sector de la Parte especial.

Por lo pronto, es imperioso recordar la prioridad de la política sobre la técnica en esta y cualesquiera otras empresas de lege ferenda. Por importantísima y aun imprescindible que sea la técnica jurídica, ella es sólo una forma impresa a ciertos contenidos, los que tienen que ser ministrados por las exigencias culturales de cada comunidad, con su sistema de valores y su correspondiente traducción política. Los especialistas no podemos preparar un proyecto o anteproyecto según nuestro leal saber y entender, sobre el que luego, a modo de pie forzado, el Parlamento habrá de discurrir, aprobándolo o rechazándolo, porque esto implicaría una delegación de la función política en un técnico, en definitiva, un simple particular. La técnica podrá arbitrar el cómo; pero la decisión de qué escoger y decidir, en una democracia representativa, compete exclusivamente al pueblo y a sus representantes ${ }^{47}$. Por ende, los lineamientos generales de la modificación deben ser fijados por el cuerpo político; luego de ello se podrá confiar a los especialistas la tarea de desarrollarlos y darles forma.

Puesto que semejantes lineamientos han brillado por su ausencia en la reforma de estos delitos y, por otra parte, tampoco podríamos sugerirlos directamente los penalistas, porque entonces actuaríamos como políticos, enmascarando una función del titular de la soberanía bajo el prestigio de la ciencia ${ }^{48}$, tenemos que contentarnos con una

47. RIVACOBA Y RIVACOBA, Manuel: Técnica y política en el sistema de la reforma penal, en Cuadernos de Política Criminal, Madrid, número 55, eneroabril de 1995, cfr. pág. (323-327) 326.

48. Ibídem.

Revista de Ciencias Sociales - Número 68 (2016) - Universidad de Valparáíso - ISSN 0716-7725-Valparaíso, Chile 
metodología negativa que se limite a hacer presente un par de rasgos de la sociedad chilena que tienen enorme incidencia en estos asuntos y que hay que compaginar con las exigencias del Derecho internacional sobre derechos del hombre, como paso previo a las decisiones técnicas acerca de la protección penal de la autonomía sexual de las personas. Primero, un autoritarismo sumamente difuso que predispone a la población, entre otras manifestaciones de intolerancia, a descalificar al sexualmente diverso y a abusar de los que comparten las inclinaciones propias, pero que son física, social o circunstancialmente más débiles ${ }^{49}$. Segundo, una represión de la sexualidad que se percibe por doquier, así en la beatería hazañera con que se disimula el tema en las relaciones sociales de las capas altas y medias, como en la chabacanería de la exhibición pública del cuerpo en programas televisivos, periódicos y revistas, represión que parece destinada a reproducirse y perdurar mientras los jóvenes no reciban en la escuela una educación que les enseñe a vivir la sexualidad como lo que ella es, una función natural en el ser humano ${ }^{50}$. No maravilla que la combinación de estos dos elementos se traduzca en distintas formas de violencia sexual, algunas

49. No es casual que una cuidadosa investigación empírica indique que las fuentes más importantes de intolerancia en Chile son el autoritarismo y, en correspondencia con ello, la homofobia. Véase AYMERICH, Jaime, CANALES, Manuel, y VIVANCO, Manuel: Encuesta tolerancia y no discriminación. Tercera medición, Fundación Facultad de Ciencias Sociales, Departamento de Sociología, Universidad de Chile, 2003, disponible en internet (http://www.libros.uchile.cl/240) págs. 36, 37 y 184.

50. El retraso en la importantísima cuestión de que las nuevas generaciones conozcan científicamente la sexualidad en la escuela ha sido objeto de algunos estudios en último tiempo, los que no trepidan en denunciar que el silencio oficial es una estrategia para negar sus derechos como personas y fortalecer la hipocresía de una sociedad sexualmente enferma. Cfr. CASAS, Lidia: "De la negación a la represión de la sexualidad adolescente en Chile", en el volumen colectivo Justicia de género y sexualidad, Centro de Derechos Humanos de la Facultad de Derecho de la Universidad de Chile, Santiago de Chile, 2012, págs. 32-54. Por cierto, la Ley número 20.418, de 28 de enero de 2010 , que fija normas sobre información, orientación y prestaciones en materia de regulación de la fertilidad, no hace sino mantener este estado de cosas cuando establece que los establecimientos educacionales reconocidos por el Estado deberán incluir dentro del ciclo de la enseñanza media un programa de educación sexual que, "según sus principios y valores, incluya contenidos que propendan a una

Facultad de Derecho y Ciencias Sociales - Universidad de Valparaíso - Chile 
bastante graves y que no ahorran siquiera a los estudiantes universitarios $^{51}$.

Ante esta situación, al Derecho penal se abren dos caminos. Uno consiste en regodearse con el subsistema de delitos y penas, exasperándolo hasta eliminar a los delincuentes y abroquelar simbólica, esto es, mañosamente a las potenciales víctimas. Es la pista que galopó el legislador con la reforma parcial de 2004 y la famosa integridad sexual. Sus frutos son conocidos, como también sabemos que la integridad o indemnidad sexuales son conceptos gaseosos a que los intereses represivos de la sexualidad pueden fácilmente colmar con contenidos ideológicos que desfiguren los intereses de la víctima, manipulada como un ser dependiente y discreto, y los de la persona del victimario, tratado como un paria y materia de descarte social. La otra vía, que no se ha recorrido aún, supone acatar los requerimientos del Derecho internacional de los derechos del hombre ${ }^{52} \mathrm{y}$, en consecuencia, poner en primer plano su libertad sexual; pasar, pues, de la función interpretativa de un bien jurídico potencialmente liberticida, a la función prospectiva, de configuración cultural, de una concepción que desapareció en el último proceso de partenogénesis de estos delitos ${ }^{53}$.

sexualidad responsable e informe de manera completa sobre los diversos métodos anticonceptivos existentes y autorizados, de acuerdo al proyecto educativo, convicciones y creencias que adopte e imparta cada establecimiento educacional en conjunto con los centros de padres y apoderados" (artículo $1^{\circ}$ ). Como se ve, el objetivo es aplastar la sexualidad con la ideología de cada establecimiento.

51. Los que, con más frecuencia de lo que sería de suponer, son víctimas de sus propios galanes o compañeros de estudios. Cfr. LEHRER, Jocelyn y LEHRER,

Evelyn: Violencia sexual y en el cortejo en estudiantes universitarios chilenos, Editorial Universitaria, Santiago de Chile, 2014, págs. 131 y ss. En págs. 41-42 anotan que "las leyes nacionales chilenas han reflejado y reforzado las normas de una sociedad conservadora y los roles tradicionales asignados a cada género", y que esto contribuye al clima de violencia sexual.

52. Por lo demás, hace ya varios años que Naciones Unidas viene instando a Chile para que adopte leyes políticas y programas que promuevan el respeto de los derechos de las personas en materia de sexualidad y reproducción. Cfr. Casas, ob. cit., pág. 54.

53. La función interpretativo-sistemática de la indemnidad sexual es argumentada a propósito de la violación en un contundente estudio de Mañalich Raffo,

Revista de Ciencias Sociales - Número 68 (2016) - Universidad de Valparaíso - ISSN 0716-7725-Valparáís, Chile 
La ruta de la libertad sexual invita a contraerlos nada más que a los de violación, abusos sexuales y corrupción grave de infantes e impúberes. La violación debiera contemplar las vías de penetración vaginal y anal, con tres modalidades ejecutivas de diferente gravedad, primero la cometida contra menores de trece años mediando violencia o intimidación, luego la perpetrada con los mismos medios contra adultos y, al final, el acceso carnal abusivo de mayores y el consentido por menores ${ }^{54}$. El régimen de los abusos sexuales podría construirse sobre el mismo esquema de la violación, siquiera precisando que la acción tiene que reflejar un significado lascivo y revestir importancia a la luz de su naturaleza, intensidad, duración, circunstancias concomitantes o las eventuales relaciones entre las partes. Márgenes mínimo y máximo suficiente, mas no excesivamente dilatados, harían superfluo un tipo calificado para los supuestos más severos -introducción de objetos o dedos, cunnilungus, anilingus, coito inter femora, sodomía ratione generis, etc., etc.-, que tampoco es necesario ni conveniente nombrar. Por último, en la corrupción sería recomendable distinguir las acciones inverecundas graves realizadas ante o que se haga ejecutar frente a terceros a un menor de trece años, por una parte, y, por otra, el

quien, en todo caso, se cuida de distinguirla de la intangibilidad y el bienestar sexuales precisamente para que las personas no pierdan su libertad dentro de la espiral de aspiraciones impersonales. Cfr. MAÑLICH RAFFO, Juan Pablo: La violación como delito contra la indemnidad sexual en el Derecho penal chileno. Una reconstrucción desde la teoría de las normas, en Ius et praxis, cit., año 20, número 2, 2014, págs. (21-70) 42 y 43 .

54. El ataque contra personas privadas de sentido, enajenadas o con algún trastorno mental grave pudiera recibir una pena superior al realizado abusando de una condición de grave desvalimiento o una relación de dependencia de la víctima adolescente. La última hipótesis, que corresponde a la médula conservable del actual estupro, sería castigada como una atenuación específica, a continuación de la violación consentida de impúberes. Asimismo, una cláusula de atipicidad tendría que velar por que no se inicie proceso alguno a causa de violación, abuso o corrupción, si tampoco hubo coerción o abuso del menor de trece y el autor no tiene más de dieciocho años de edad. Claro está que el problema de los lances sexuales entre adolescentes se resolvería de raíz si la Justicia penal se convence de que no debe intervenir en caso alguno por hechos antijurídicos de aquéllos, devolviéndolos al lugar del que nunca debieron salir, los tribunales civiles de la familia.

Facultad de Derecho y Ciencias Sociales - Universidad de Valparaíso - Chile 
favorecimiento de la prostitución de mayores de trece y menores de dieciocho años para satisfacer deseos de otro ${ }^{55}$. En ambos casos, las penas no debieran superar las del abuso corpóreo.

El eje de la libertad sexual es capaz de responder con éxito a la doble objeción de que las leyes no sancionan entre estos delitos el hecho de impedir a una persona que ejerza su sexualidad como le plazca y que los individuos menores o perturbados mentalmente tendrían indemnidad, pero no autonomía sexual. Lo primero se presenta igualmente en otros atentados contra la libertad, sea debido a la menor entidad del estorbo frente al constreñimiento, sea porque entorpecerla no podría en absoluto conmover la especie de libertad de que se trate. Por ejemplo, es secuestro impedir que un sujeto abandone el lugar en que se halla, pero no vedarle el paso a un sitio donde quiere entrar. Y en cuanto a lo segundo, no es verdad que niños y enajenados carezcan de libertad sexual. Lo que pasa es que no están o todavía no están en situación de ejercerla conscientemente, asumiéndola con responsabilidad. El cotejo con otros delitos brinda una comprobación paralela. Las leyes castigan la substracción de menores, y el Código chileno precisamente como un delito contra la libertad, una forma agravada de secuestro. Se pena también la lesión que deja a un menor impúber impotente, bastando para ello que tuviese en potencia la capacidad de copular o procrear en el futuro.

Por último, ayudaría mucho eliminar las disposiciones comunes del parágrafo 7, título VII, comenzando por las acopladas desordenadamente en el último tiempo. En su lugar, pudieran quedar sólo tres sencillas reglas: una que acuerde carácter mixto a la acción penal, otra que regule el perdón libremente otorgado por el ofendido capaz como causa de extinción de la responsabilidad penal del ofensor y, en defecto de perdón, la última que establezca, como alternativa a las penas privativas de la libertad ${ }^{56}$ de todos los delitos cometidos contra

55. Acompañado de una agravación cuando el menor al que se intenta prostituir tiene menos de trece años.

56. Suponiendo que se quiera insistir en su empleo, ninguna de ellas debiera igualar la penalidad del homicidio.

Revista de Ciencias Sociales - Número 68 (2016) - Universidad de Valparáíso - ISSN 0716-7725-Valparaíso, Chile 
adolescentes o adultos, una pena de contenido reparador, señalándose para el efecto un abanico legal de posibilidades tan amplio como sea imaginable, al interior del cual pueda el juez elegir la reparación más adecuada al daño directo o indirecto producido por el delito. La coerción reparadora sería independiente, como la sanción pública que es, del deber de indemnizar perjuicios, un problema de Derecho privado ${ }^{57}$.

\section{Bibliografía}

AYMERICH, Jaime, CANALES, Manuel y VIVANCO, Manuel. Encuesta tolerancia y no discriminación. Tercera medición, Fundación Facultad de Ciencias Sociales, Departamento de Sociología, Universidad de Chile, 2003, disponible en internet (http:// www.libros.uchile.cl/240).

BASCUÑ́N RODRÍGUEZ, Antonio. "La inconsistencia del Derecho penal sexual moderno", en el volumen La ciencia penal en la

Universidad de Chile. Libro homenaje a los profesores del Departamento de Ciencias penales de la Facultad de Derecho de la Universidad de Chile, coordinado por Juan Pablo Mañalich Raffo, Santiago de Chile, 2013, págs. 405-433.

"La prohibición penal de la homosexualidad masculina juvenil (comentario a la sentencia del Tribunal Constitucional de 4 de enero de 2011, rol No 1683-2010)", en la revista Estudios públicos, de Santiago de Chile, número 124, 2011.

BULLEMORE GALLARDO, Vivian. Derecho penal. Tratado de jurisprudencia y doctrina, 2 vols., Thomson Reuters, Santiago de Chile, 2011.

BULLEMORE GALLARDO, Vivian y MACKINNON ROEHRS, John. Curso de Derecho penal, publicados, 3 vols., Lexis Nexis, Santiago de Chile, 2005.

CABEZAS, Carlos. "Prescripción de los delitos contra la indemnidad y libertad sexual de los menores de edad: problemas aplicativos

57. De la reparación como único sentido racional de las penas en general, discurrimos en nuestro libro Elementi di Filosofia giuridico-penale, edición italiana al cuidado de Gabriele Fornasari y Asessandra Macillo, Editoriale Scientifica, Napoli, 2015, págs. 183-201.

Facultad de Derecho y Ciencias Sociales - Universidad de Valparaíso - Chile 
del artículo 369 quáter del Código penal”, en la revista Política Criminal, de Santiago de Chile, vol. 8, número 16, diciembre de 2013, págs. 386407.

CARNEVALI RODRÍGUEZ, Raúl. "Algunas precisiones respecto de los delitos de producción de material pornográfico infantil, de favorecimiento a la prostitución de menores y de obtención de servicios sexuales”, Informe en Derecho, número 2, Defensoría Penal Pública, Santiago de Chile, 2012.

CASAS, Lidia. "De la negación a la represión de la sexualidad adolescente en Chile", en el volumen colectivo Justicia de género y sexualidad, Centro de Derechos Humanos de la Facultad de Derecho de la Universidad de Chile, Santiago de Chile, 2012, págs. 32-54.

COX LEIXELARD, Juan Pablo. Delitos de posesión. Bases para una dogmática, Editorial B. de F., Montevideo-Buenos Aires, 2012;

Juan Pablo Cox Leixelard: "Los delitos de producción, adquisición y tenencia maliciosa de material pornográfico como figuras expansivas del Derecho penal", en la Revista de Derecho, Pontificia Universidad Católica de Valparaíso, número XXVI, primer semestre de 2005, págs. 145-154.

DÍEZ RIPOLLÉS, José Luis. Delitos y penas en España, Catarata, Madrid, 2015; José Luis Díez Ripollés: Exhibicionismo, pornografía y otras conductas sexuales provocadoras. (La frontera del Derecho penal sexual), Bosch, Barcelona, 1982.

ESQUINAS VALVERDE, Patricia. "El tipo de mera posesión de pornografía infantil en el Código penal español (art. 189.2): razones para su destipificación”, en la Revista de Derecho penal y Criminología, Madrid, $2^{a}$ Época, número 18, julio de 2006, págs. 171-228.

FERNÁNDEZ CRUZ, José Ángel. "Los delitos de violación y estupro del artículo 365 bis del Código penal: una racionalización desde el mandato de lex stricta y el principio de lesividad. Especial referencia a la introducción de dedos u otras partes del cuerpo", en la revista Ius et Praxis, Talca, año 13, número 2, 2007, págs. 105-135.

GUZMÁN DALBORA, José Luis. "Apreciación y reprobación de la reforma de los delitos contra la honestidad en Chile", publicado en el Anuario de Derecho penal, de Lima, 1999-2002, págs. 201-244, y el Anuario de la Facultad de Ciencias Jurídicas de la Universidad de Antofagasta, 2000, págs. 127-172.

Revista de Ciencias Sociales - Número 68 (2016) - Universidad de Valparaíso - ISSN 0716-7725-Valparáís, Chile 
"Bosquejo y apreciación de la reciente reforma penal en Chile", en el volumen La política legislativa penal iberoamericana en el cambio de siglo, coordinado por José Luis Díez Ripollés y Octavio García Pérez, Edisofer y B. de F., Madrid y Buenos AiresMontevideo, 2008, págs. 167-199.

"De la extinción de la responsabilidad penal", en Politoff Lifschitz y Ortiz Quiroga (directores), Texto y comentario del Código penal chileno, publicado, 1 vol., Editorial Jurídica de Chile, Santiago de Chile, 2002, págs. 433-487.

"Introduzione: Il Codice penale cileno nel prisma del tempo", en Codice penale della Repubblica del Cile, a cura di Gabriele Fornasari e Emanuele Corn, Cedam, Padova, 2013, págs. IXXXXIV.

_ La pena y la extinción de la responsabilidad penal. Primera parte: penas y medidas de seguridad; sistemas penales; clasificaciones de las penas; las penas en particular, Legalpublishing, Santiago de Chile, 2008.

"La trata de personas y el problema de su bien jurídico", en la Revista procesal penal, de Santiago de Chile, número 62, agosto de 2007, págs. 9-19, con versión portuguesa, por Nuno Brandão, "O tráfico de pessoas e o problema do seu bem jurídico", en la Revista Portuguesa de Ciência Criminal, Coimbra, año 18, número 4, octubre-diciembre de 2008, págs. 447-464;

"Relaciones del Derecho penal con el Derecho constitucional, y su concreción en la Constitución política chilena (1980)”, en el Anuario de Filosofía Jurídica y Social, publicación de la Sociedad Chilena de Filosofía Jurídica y Social, Edeval, Valparaíso, número 12, 1994, págs. 165-199.

"Una especial versión del autoritarismo penal en sus rasgos fundamentales: la «doctrina» de la seguridad ciudadana”, en la Revista brasileira de Ciências criminais, de São Paulo, año 11, enero-marzo de 2003, págs. 66-78, adelantado en Gaceta Jurídica, de Santiago de Chile, número 265, julio de 2002, págs. 7-17.

HORVITZ LENNON, María Inés. "Delitos sexuales, libertad personal y protección de la moral colectiva”. En: Apuntes de Derecho, Universidad Diego Portales, Santiago de Chile, número 3, 1998.

Facultad de Derecho y Ciencias Sociales - Universidad de Valparaíso - Chile 
Informe de la Comisión Nacional sobre Prisión Política y Tortura, Santiago

de Chile, 2005; Luis Jiménez de Asúa: Libertad de amary derecho a morir. Ensayo de un criminalista sobre eugenesia y eutanasia, Depalma, Buenos Aires, $7^{\mathrm{a}}$ ed., 1984.

KÜNSEMÜLLER LOEBENFELDER, Carlos. "Delitos de pornogra-

fía infantil (modificaciones legales anunciadas y problemas «ad portas»)". En: Gaceta Jurídica, de Santiago de Chile, número 273, marzo de 2003, págs. 7-13.

LEHRER, Jocelyn y Evelyn. Violencia sexual y en el cortejo en estudiantes universitarios chilenos, Editorial Universitaria, Santiago de Chile, 2014.

MALDONADO FUENTES, Francisco. "Tratamiento de la nueva regulación de delitos sexuales, en el volumen Problemas actuales de Derecho penal”, Universidad Católica de Temuco, 2003, págs. 227 265.

Complemento a Garrido Montt, Mario, Derecho penal, publicados, 4 vols., Editorial Jurídica de Chile, Santiago de Chile, t. III (Parte especial), $3^{\mathrm{a}}$ ed., actualizada, 2007, págs. 325-436.

MAÑALCH RAFFO, Juan Pablo. "La violación como delito contra la indemnidad sexual en el Derecho penal chileno. Una reconstrucción desde la teoría de las normas”. En: Ius et praxis, cit., año 20, número 2, 2014, págs. 21-70.

MATUS ACUÑA, Jean Pierre. Evolución histórica de la doctrina penal chilena desde 1874 hasta nuestros días, Legalpublishing, Santiago de Chile, 2011.

MAYER LUX, Laura. "Almacenamiento de pornografía en cuya elaboración se utilice a menores de dieciocho años: un delito asistemático, ilegítimo e inútil”, en la revista Política Criminal, de Santiago de Chile, vol. 9, número 17, julio de 2014, págs. 25-57.

OLIVER CALDERÓN, Guillermo. Delitos contra la propiedad, Legalpublishing-Thomson Reuters, Santiago de Chile, 2013.

—_La aplicación temporal de la nueva regla del cómputo del plazo de prescripción de la acción penal en delitos sexuales con víctimas menores de edad". En: Revista de Derecho, Pontificia Universidad Católica de Valparaíso, cit., número XXIX, $2^{\circ}$ Semestre de 2007, págs. 257-266.

Revista de Ciencias Sociales - Número 68 (2016) - Universidad de Valparáíso - ISSN 0716-7725-Valparaíso, Chile 
OXMAN VILCHES, Nicolás. "Consideraciones críticas en torno al artículo $4^{\circ}$ de la Ley de Responsabilidad Penal Juvenil", en el volumen Estudios de Ciencias penales. Hacia una racionalización del Derecho penal, coordinado por José Ángel Fernández Cruz, Legalpublishing, Santiago de Chile, 2008, págs. 89-108.

PEÑA WASAFF, Silvia y SANTIBÁÑEZ TORRES, María Elena. "La prescripción de delitos sexuales contra menores de edad. (Modificaciones introducidas por la Ley No 20.207, de 31 de agosto de 2007)", en Microjuris, enero de 2008.

POLITOFF LIFSCHITZ, Sergio, MATUS ACUÑA, Jean Pierre y RAMÍREZ GUZMÁN, María Cecilia. Lecciones de Derecho penal chileno, Parte especial, Editorial Jurídica de Chile, Santiago de Chile, $2^{\mathrm{a}}$ ed., actualizada, 2004.

RAMÍREZ GUZMÁN, María Cecilia. La regulación penal de la prostitución infantil. Derecho internacional, de la Unión Europea y comparado. Especial referencia a los sujetos involucrados, Dictus Publishing, Saarbrücken, 2014.

RIVACOBA y RIVACOBA, Manuel de. Evolución histórica del Derecho penal chileno, Edeval, Valparaíso, 1991.

_- "Técnica y política en el sistema de la reforma penal". En: Cuadernos de Política Criminal, Madrid, número 55, enero-abril de 1995, págs. 323-327.

RODRÍGUEZ COLLAO, Luis. "Criterios de agravación de la pena en los delitos de producción, difusión y almacenamiento de pornografía infantil", en la Revista de Derecho, Universidad Austral de Chile, Valdivia, vol. XXVI, número 1, julio de 2013, págs. 145-166.

- Delitos sexuales, Editorial Jurídica de Chile, Santiago de Chile, $2^{a}$ ed., actualizada, 2014; Luis Rodríguez Collao, "Sobre la regulación de los delitos contra la integridad sexual en el Anteproyecto de Código penal”. En: Política Criminal, cit., número 1, 2006, págs. 1-19.

TALADRIZ EGUILUZ, María José. "Decisiones judiciales en el ámbito penal acerca del concepto «convivencia»". En: Revista de Ciencias

Penales, cit., volumen XLI, número 4, 2014, págs. 79-101.

VAN WEEZEL de LA CRUZ, Alex. La garantía de tipicidad en la jurisprudencia del Tribunal Constitucional, Abeledo-Perrot, Santiago de Chile, 2011.

Facultad de Derecho y Ciencias Sociales - Universidad de Valparaíso - Chile 